Check for updates

Cite this: RSC Adv., 2021, 11, 9740

Received 18th January 2021

Accepted 24th February 2021

DOI: 10.1039/d1ra00440a

rsc.li/rsc-advances

\section{A general method for the synthesis of covalent and ionic amine borane complexes containing trinitromethyl fragments $\uparrow$}

\author{
Jin Wang, ${ }^{\text {ac }}$ Ming-Yue Ju, ${ }^{a}$ Xi-Meng Chen ${ }^{\star a}$ and Xuenian Chen (D)*ab \\ A general approach for the synthesis of covalent and ionic amine borane complexes containing \\ trinitromethyl fragments has been developed through metathesis reactions between amine chloroborane \\ complexes and potassium salt of trinitromethyl $\left(\mathrm{K}\left[\mathrm{C}\left(\mathrm{NO}_{2}\right)_{3}\right]\right)$. Five covalent and ionic trinitromethyl amine \\ borane complexes have been synthesized in good yields with high purity and it is found that the ionic \\ complex, $\left[\mathrm{H}_{2} \mathrm{~B}\left(\mathrm{NH}_{3}\right)_{2}\right]\left[\mathrm{C}\left(\mathrm{NO}_{2}\right)_{3}\right]$, might be a promising energetic material on the basis of the investigation \\ of its thermal decomposition behaviour.
}

\section{Introduction}

Nitroform $\left(\mathrm{CH}\left(\mathrm{NO}_{2}\right)_{3}\right)$ holds a unique position among nitro compounds as it is a valuable starting material for the preparation of propellant and explosive components due to its high oxygen content. ${ }^{1}$ Ioffe group reported the syntheses and transformations of trinitromethylborane complexes with cyclic ethers and aromatic N-containing heterocycles, and also discussed the principle of the reactions. ${ }^{2}$ However, they attempted to obtain $N, N$-dinitroamidoborane complexes using the same method, but failed. ${ }^{2 a}$ Klapötke and coworkers studied the reactions of boron oxide $\left(\mathrm{B}_{2} \mathrm{O}_{3}\right)$ with various nitro-substituted ethanols (2-nitroethanol, 2-fluoro-2,2-dinitroethanol, and 2,2,2-trinitroethanol) to furnish the corresponding nitroethyl borates $\mathrm{B}\left(\mathrm{OCH}_{2} \mathrm{CH}_{2} \mathrm{NO}_{2}\right)_{3}, \mathrm{~B}\left(\mathrm{OCH}_{2} \mathrm{CF}\left(\mathrm{NO}_{2}\right)_{2}\right)_{3}$, and $\mathrm{B}\left(\mathrm{OCH}_{2}-\right.$ $\left.\mathrm{C}\left(\mathrm{NO}_{2}\right)_{3}\right)_{3}{ }^{3}$ The compound $\mathrm{B}\left(\mathrm{OCH}_{2} \mathrm{C}\left(\mathrm{NO}_{2}\right)_{3}\right)_{3}$ can be used as green-light-emitting pyrotechnic composition. ${ }^{4}$

Interestingly, $\mathrm{C}\left(\mathrm{NO}_{2}\right)_{3}$, as an oxidizing group, can be introduced into the design of high-energy molecules to co-exist with powerful reducing borohydride in a single covalently bonded structure. ${ }^{5}$ In 2013, Christe group used $\mathrm{CH}\left(\mathrm{NO}_{2}\right)_{3}$ and $\mathrm{NaBH}_{4}$ as starting materials to synthesize $\left[\mathrm{Na}(\text { glyme })_{2}\right]\left[\mathrm{BH}_{3} \mathrm{C}\left(\mathrm{NO}_{2}\right)_{3}\right] .^{5}$ Subsequently, they employed metathesis reactions to convert this salt into $\mathrm{PNP}^{+}$and $\mathrm{PPh}^{4+}$ analogs that were stable for several months at room temperature. In 2015, ammonia-dinitroamidoborane, $\mathrm{NH}_{3} \mathrm{BH}_{2} \mathrm{~N}\left(\mathrm{NO}_{2}\right)_{2}$ was synthesized by the

${ }^{a}$ School of Chemistry and Chemical Engineering, Henan Key Laboratory of Boron Chemistry and Advanced Energy Materials, Henan Normal University, Xinxiang, Henan 453007, China.E-mail: xnchen@htu.edu.cn; chenximeng@htu.edu.cn

${ }^{b}$ Green Catalysis Center and College of Chemistry, Zhengzhou University, Zhengzhou, Henan 450001, China

'College of Chemistry and Chemical Engineering, Mudanjiang Normal University, Mudanjiang, Heilongjiang 157011, China

$\dagger$ Electronic supplementary information (ESI) available. See DOI: 10.1039/d1ra00440a reaction of dinitroamine $\left(\mathrm{HN}\left(\mathrm{NO}_{2}\right)_{2}\right)$ with ammonia borane $\left(\mathrm{NH}_{3} \mathrm{BH}_{3}\right)$. This compound is expected to have a good performance as an explosive being comparable to that of pentaerythritol tetranitrate and significantly greater than that of trinitrotoluene. ${ }^{6}$ So, highly energetic oxidized analogs have attracted attention recently.

$\mathrm{NH}_{3} \mathrm{BH}_{3}$, a potential hydrogen storage material, has received immense interest in the past twenty years owing to its high percentage of hydrogen (19.6 wt\%), excellent stability at room temperature, and release of hydrogen under mild conditions. ${ }^{7}$ It can also provide both a proton and hydride in chemical reactions under mild conditions. ${ }^{8}$ In $\mathrm{NH}_{3} \mathrm{BH}_{3}$, the nitrogen atom can be bonded to proton, hydrocarbon, hydroxyl, oxygen and other groups, ${ }^{9}$ and the boron atom can be bonded to hydride, hydrocarbon, oxygen, oxynitride, halogen and other electron donors that can interact with the empty orbital on boron. ${ }^{10}$ Many derivatives could be obtained from $\mathrm{NH}_{3} \mathrm{BH}_{3}$, including ammonia monochloroborane $\left(\mathrm{NH}_{3} \mathrm{BH}_{2} \mathrm{Cl}\right)^{11-14}$ which is an important intermediate for the synthesis of a series of more complex boron compounds ${ }^{15}$ such as $\mathrm{R}_{1} \mathrm{R}_{2} \mathrm{~N}=\mathrm{BH}_{2}$ (ref. $12 a$ ) and amorphous boron nitride. ${ }^{11 b}$

In this work, ammonia and amine monochloroborane complexes $\left(\mathrm{ABH}_{2} \mathrm{Cl}, \mathrm{A}=\mathrm{NH}_{3}\right.$, aliphatic primary, secondary, tertiary amine, and diamines, 1 ) were treated with $\mathrm{K}\left[\mathrm{C}\left(\mathrm{NO}_{2}\right)_{3}\right]$, a milder oxidizing reagent in comparison with $\mathrm{CH}\left(\mathrm{NO}_{2}\right)_{3},{ }^{16}$ to prepare target product 3 , with the general formula of $\mathrm{ABH}_{2}-$ $\mathrm{C}\left(\mathrm{NO}_{2}\right)_{3}$, containing both reducing and oxidizing fragments in a single covalently bonded structure. Furthermore, an ionic complex, $\left[\mathrm{H}_{2} \mathrm{~B}\left(\mathrm{NH}_{3}\right)_{2}\right]\left[\mathrm{C}\left(\mathrm{NO}_{2}\right)_{3}\right]$, was synthesized from $3 \mathrm{a}$.

\section{Results and discussion}

The reactions of each amine borane complex $\mathrm{ABH}_{3}(\mathbf{2 a}-\mathbf{d})$ with $\mathrm{HCl}$ diethyl ether solution at room temperature resulted in the formation of amine monochloroborane complexes (1a-d) in 


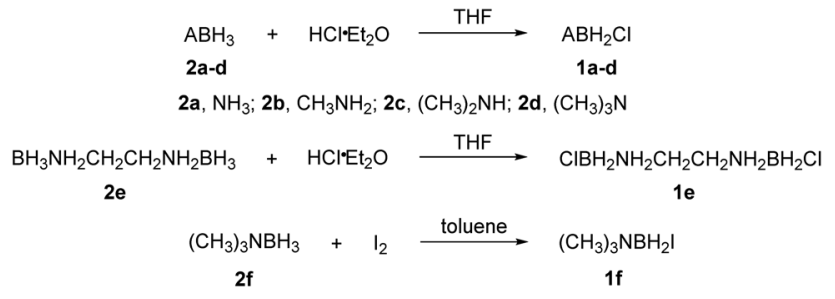

Scheme 1 Synthesis of compounds $1 a-f$.

good yields. Ethylenediaminebisborane (2e) reacted with $\mathrm{HCl} \cdot \mathrm{Et}_{2} \mathrm{O}$ at $1: 2$ ratio to form $\mathrm{ClBH}_{2} \mathrm{NH}_{2} \mathrm{CH}_{2} \mathrm{CH}_{2} \mathrm{NH}_{2} \mathrm{BH}_{2} \mathrm{Cl}$ (1e). Trimethylamine borane (2f) reacted with iodine to afford trimethylamine monoiodoborane complex (1f) (Scheme 1). These amine halogenated borane complexes (1a-f) further reacted with $\mathrm{K}\left[\mathrm{C}\left(\mathrm{NO}_{2}\right)_{3}\right]$ to produce the products (Table 1, 3a-c) by metathesis reactions. Compound (3e) (Table 1) was also synthesized by the reaction of $1 \mathrm{e}$ with $\mathrm{K}\left[\mathrm{C}\left(\mathrm{NO}_{2}\right)_{3}\right]$ according to Scheme 2. It should be noted that ammonia monochloroborane (1a) can further react with ammonia gas in THF to afford $\left[\mathrm{H}_{2} \mathrm{~B}\left(\mathrm{NH}_{3}\right)_{2}\right] \mathrm{Cl}(\mathbf{1 g})((\mathrm{a})$ in Scheme 3). 1a is a covalent complex in which the $\mathrm{Cl}-\mathrm{B}$ bond is a typical covalent bond, in accordance with amine monochloroborane complexes 1a-d. However, $\mathbf{1 g}$ shows a ionic behaviour, similar to the diammoniate of diborane $\left(\left[\mathrm{H}_{2} \mathrm{~B}\left(\mathrm{NH}_{3}\right)_{2}\right]\left[\mathrm{BH}_{4}\right]\right) .{ }^{17}$ The reaction of $\mathbf{1 g}$ and $\mathrm{K}\left[\mathrm{C}\left(\mathrm{NO}_{2}\right)_{3}\right]$ leads to the formation of an ionic compound, $\mathbf{3 g}$ (Scheme 3). On the other hand, attempts for the syntheses of $\left(\mathrm{CH}_{3}\right)_{3^{-}}$ $\mathrm{NBH}_{2} \mathrm{C}\left(\mathrm{NO}_{2}\right)_{3}$ have failed, ether by chloroborane or iodoborane intermediates, probably due to the steric hindrance of the trimethylamine group. In general, five amine borane containing the trinitromethyl group, four covalent and one ionic complexes (Table 1, 3a-c, 3e, 3g), were successfully synthesized in good yields with high purity.

It is worthy to note that $\mathbf{3 g}$ was firstly synthesized by Ioffe group in 2014 (3a in Scheme 3). ${ }^{2 b}$ We provide two alternative routes in this work. Scheme 3a shows the Ioffe group's method as described above, ${ }^{2 b} \mathbf{1 a}$ reacted with excess $\mathrm{NH}_{3}$ to convert into $\mathbf{~} \mathrm{g}$ and then reacted with $\mathrm{K}\left[\mathrm{C}\left(\mathrm{NO}_{2}\right)_{3}\right]$ to form a yellow residue $3 \mathbf{g}$

Table 1 Synthesis of $3 a-g$ from $1 \mathrm{a}-\mathrm{g}$ and $\mathrm{K}\left[\mathrm{C}\left(\mathrm{NO}_{2}\right)_{3}\right]$

\begin{tabular}{|c|c|c|c|c|}
\hline & & $\begin{array}{r}+\mathrm{ABH}_{2} \mathrm{X}- \\
\text { 1a-g }\end{array}$ & $\begin{array}{c}\mathrm{O}_{2} \mathrm{~N} \mathrm{NOO}_{2} \\
\mathrm{O}_{2} \mathrm{~N} \mathrm{BH}_{2} \\
3 \mathrm{a}-\mathrm{g}\end{array}$ & \\
\hline Entry & Comps. & $\mathrm{A}$ & $\mathrm{X}(\mathbf{1})$ & Yields of $3^{a}(\%)$ \\
\hline 1 & $\mathbf{a}$ & $\mathrm{NH}_{3}$ & $\mathrm{Cl}$ & 65 \\
\hline 2 & b & $\mathrm{CH}_{3} \mathrm{NH}_{2}$ & $\mathrm{Cl}$ & 62 \\
\hline 3 & c & $\left(\mathrm{CH}_{3}\right)_{2} \mathrm{NH}$ & $\mathrm{Cl}$ & 67 \\
\hline 4 & d & $\left(\mathrm{CH}_{3}\right)_{3} \mathrm{~N}$ & $\mathrm{Cl}$ & No reaction \\
\hline 5 & e & $\left(\mathrm{CH}_{2} \mathrm{NH}_{2}\right)_{2}$ & $\mathrm{Cl}$ & 62 \\
\hline 6 & f & $\left(\mathrm{CH}_{3}\right)_{3} \mathrm{~N}$ & I & No reaction \\
\hline 7 & $\mathrm{~g}$ & $\left(\mathrm{NH}_{3}\right)_{2}$ & $\mathrm{Cl}$ & $65^{b}$ \\
\hline
\end{tabular}

${ }^{a}$ Isolated yield. ${ }^{b}$ Yield of synthesis method a.
$2 \mathrm{~K}\left[\mathrm{C}\left(\mathrm{NO}_{2}\right)_{3}\right]+\mathrm{ClBH}_{2} \mathrm{NH}_{2} \mathrm{CH}_{2} \mathrm{CH}_{2} \mathrm{NH}_{2} \mathrm{BH} \mathrm{Cl}_{2} \stackrel{\mathrm{Et}}{\longrightarrow} 2 \mathrm{KCl}+\left(\mathrm{NO}_{2}\right)_{3} \mathrm{CBH}_{2} \mathrm{NH}_{2} \mathrm{CH}_{2} \mathrm{CH}_{2} \mathrm{NH}_{2} \mathrm{BH}_{2} \mathrm{C}\left(\mathrm{NO}_{2}\right)_{3}$

$1 e$

$3 e$

Scheme 2 Synthesis of compound 3e.

in a yield of $65 \%$. In our work, as shown in Scheme $3 \mathrm{~b}, \mathrm{~K}$ $\left[\mathrm{C}\left(\mathrm{NO}_{2}\right)_{3}\right]$ directly reacted with $1 \mathrm{a}$ in liquid $\mathrm{NH}_{3}$ at $-78{ }^{\circ} \mathrm{C}$ to give yellow product $3 \mathrm{~g}$ with a yield of $68 \%$; and Scheme $3 \mathrm{c}, \mathrm{K}$ $\left[\mathrm{C}\left(\mathrm{NO}_{2}\right)_{3}\right]$ reacted with 1a in ethyl ether first and then with excess $\mathrm{NH}_{3}$ gas to give $3 \mathrm{~g}$, the yield was $59 \%$. In comparison, pathway (b) is a one-step procedure with high efficiency. Further study shows that $\mathbf{3 g}$ is an ionic complex, it has good solubility in organic solvents, such as tetrahydrofuran (THF) and acetonitrile $\left(\mathrm{CH}_{3} \mathrm{CN}\right)$, different from $\left(\mathrm{NH}_{3}\right)_{2} \mathrm{BH}_{2} \mathrm{Cl}^{14} 3 \mathrm{~g}$ also showed good stability towards air and moisture even for several months at room temperature. Thus, it has wide potential applications as a high-energy-density material.

The ${ }^{11} \mathrm{~B}$ NMR data of $\mathrm{ABH}_{2} \mathrm{X}\left(\mathrm{X}=\mathrm{Cl}\right.$, I, and $\left.\mathrm{C}\left(\mathrm{NO}_{2}\right)_{3}\right)$ are summarized in Table 2. The chemical shift of the $\mathrm{B}$ atom in $\mathrm{ABH}_{2} \mathrm{C}\left(\mathrm{NO}_{2}\right)_{3}$ shifts downfield about $4 \mathrm{ppm}$ in comparison with that of the $\mathrm{B}$ atom in the corresponding $\mathrm{ABH}_{2} \mathrm{Cl}$ complexes. This can be attributed the strong electron-withdrawing ability of the $\mathrm{C}\left(\mathrm{NO}_{2}\right)_{3}$ group relative to $\mathrm{Cl}$. With increasing each one methyl group bonded in the $\mathrm{N}$ atom, on the other hand, the chemical shift of the B signal shifts downfield about 2 ppm (Table 2) in either $\mathrm{ABH}_{2} \mathrm{Cl}$ or $\mathrm{ABH}_{2} \mathrm{C}\left(\mathrm{NO}_{2}\right)_{3}$ complexes. These change trends are consistent with those of the chemical shift of the $\mathrm{B}$ atom in amine boranes. For the amine chloroborane complexes or trinitromethylamidoborane complexes, whether the compound is mono-substituted (1) and $\mathbf{3 b}$ ) or bis-substituted (1e and $\mathbf{3 e}$ ), little effect was observed on the chemical shift of $\mathrm{ABH}_{2} \mathrm{X}$ (Table 2 , entries 2 and 5). The B signal of $\left[\mathrm{H}_{2} \mathrm{~B}\left(\mathrm{NH}_{3}\right)_{2}\right] \mathrm{Cl}$ and $\left[\mathrm{H}_{2} \mathrm{~B}\left(\mathrm{NH}_{3}\right)_{2}\right]\left[\mathrm{C}\left(\mathrm{NO}_{2}\right)_{3}\right]$ are almost identical (Table 2, entry 7) because they are ionic compounds so that the effect of the different counter-anion on the chemical shift of the B atom in the $\left[\mathrm{H}_{2} \mathrm{~B}\left(\mathrm{NH}_{3}\right)_{2}\right]^{+}$cation is weak. In contrast, the effect is more pronounced in covalent complexes (1a-f and $\mathbf{3 a - c}, \mathbf{e})$ as described above because of the direct N-B and B-C bonding. In addition, the chemical shift of the proton of the $\mathrm{BH}_{2}$ group in $\mathrm{ABH}_{2} \mathrm{C}\left(\mathrm{NO}_{2}\right)_{3}$ in ${ }^{1} \mathrm{H}$ NMR are also summarized in Table $\mathrm{S} 1, \uparrow$ all proton signals appeared at about $\delta 2 \mathrm{ppm}$, similar to those of $\mathrm{ABH}_{2} \mathrm{Cl}^{1{ }^{11-14}}$ This indicated that the change of substituents may not influence the chemical shift of the $\mathrm{BH}_{2}$ group in $\mathrm{ABH}_{2} \mathrm{C}\left(\mathrm{NO}_{2}\right)_{3}$.

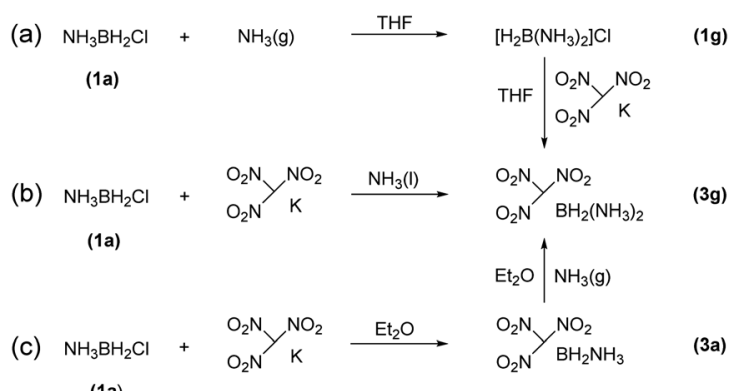

Scheme 3 The methods for the synthesis of $3 \mathrm{~g}$. 
Table $2{ }^{11} \mathrm{~B}$ NMR of 1 and $3^{a}$

\begin{tabular}{|c|c|c|c|c|c|c|}
\hline Entry & Comps. & A & $\begin{array}{l}\mathrm{X} \\
(\mathbf{1})\end{array}$ & $\begin{array}{l}{ }^{11} \mathrm{~B} \\
\mathrm{NMR}(\mathrm{ppm})\end{array}$ & X (3) & $\begin{array}{l}{ }^{11} \mathrm{~B} \\
\mathrm{NMR}(\mathrm{ppm})\end{array}$ \\
\hline 1 & a & $\mathrm{NH}_{3}$ & $\mathrm{Cl}$ & -8.73 & $\mathrm{C}\left(\mathrm{NO}_{2}\right)_{3}$ & -4.8 \\
\hline 2 & b & $\mathrm{CH}_{3} \mathrm{NH}_{2}$ & $\mathrm{Cl}$ & -6.36 & $\mathrm{C}\left(\mathrm{NO}_{2}\right)_{3}$ & -2.32 \\
\hline 3 & c & $\left(\mathrm{CH}_{3}\right)_{2} \mathrm{NH}$ & $\mathrm{Cl}$ & -3.47 & $\mathrm{C}\left(\mathrm{NO}_{2}\right)_{3}$ & -0.22 \\
\hline 4 & d & $\left(\mathrm{CH}_{3}\right)_{3} \mathrm{~N}$ & $\mathrm{Cl}$ & 0.21 & $\mathrm{C}\left(\mathrm{NO}_{2}\right)_{3}$ & - \\
\hline 5 & e & $\left(\mathrm{NH}_{2} \mathrm{CH}_{2}\right)_{2}$ & $\mathrm{Cl}$ & $-6.47^{b}$ & $\mathrm{C}\left(\mathrm{NO}_{2}\right)_{3}$ & $-2.93^{c}$ \\
\hline 6 & f & $\left(\mathrm{CH}_{3}\right)_{3} \mathrm{~N}$ & I & -10.57 & $\mathrm{C}\left(\mathrm{NO}_{2}\right)_{3}$ & - \\
\hline 7 & $\mathrm{~g}$ & $\left(\mathrm{NH}_{3}\right)_{2}$ & $\mathrm{Cl}$ & -13.54 & $\mathrm{C}\left(\mathrm{NO}_{2}\right)_{3}$ & -13.06 \\
\hline
\end{tabular}

${ }^{a} \mathrm{~A}$ is the lewis base, $\mathrm{X}$ is the substituent group. ${ }^{b}$ Molecular formula $\left(\mathrm{NH}_{2} \mathrm{CH}_{2} \mathrm{BH}_{2} \mathrm{Cl}\right)_{2} \cdot{ }^{c}$ Molecular formula $\left[\mathrm{NH}_{2} \mathrm{CH}_{2} \mathrm{BH}_{2} \mathrm{C}\left(\mathrm{NO}_{2}\right)_{3}\right]_{2}$.

Thermal decomposition of $\mathbf{3 a}$ and $\mathbf{3} \mathbf{g}$ was studied by DSC and TGA-MS. As shown in Fig. 1 and 2, thermal decomposition resulted in the generation of $\mathrm{H}_{2}, \mathrm{~N}_{2}, \mathrm{NH}_{3}, \mathrm{CO}_{2}, \mathrm{~N}_{2} \mathrm{O}$ and $\mathrm{NO}_{2}$, hence the decomposition is believed to proceed according to eqn (1) and (2), respectively.

Gaseous products were analysed by mass spectrometry (MS), and solid residues were determined by IR and XRD. It was observed that 3a starts decomposing at $98{ }^{\circ} \mathrm{C}$ and the first-stage weight loss is only $1.7 \mathrm{wt} \%$, corresponding to the evolution of hydrogen and nitrogen dioxide, and the $\mathrm{m} / \mathrm{z} 44$ signal is assigned to $\mathrm{N}_{2} \mathrm{O}$ or $\mathrm{CO}_{2}$ evolution. The decomposition behaviour of $\mathbf{3 a}$ is similar to that of the energetic oxidizer hydrazinium nitroformate $\left(\mathrm{N}_{2} \mathrm{H}_{5} \mathrm{C}\left(\mathrm{NO}_{2}\right)_{3}, \mathrm{HNF}\right)$, as shown in eqn (3). ${ }^{18}$ The second-stage weight loss is as large as $31.2 \mathrm{wt} \%$, associated with $\mathrm{H}_{2}, \mathrm{~N}_{2}, \mathrm{NH}_{3}, \mathrm{CO}_{2}, \mathrm{~N}_{2} \mathrm{O}$ and $\mathrm{NO}_{2}$ evolution. Both the first and second steps for $\mathbf{3 a}$ are exothermic events, the $m / z 2,28,17$, 44 , and 46 signals recorded by the MS during the TGA-MS experiment to $400{ }^{\circ} \mathrm{C}$ are overlaid in Fig. 1b. At higher temperatures, it further decomposes and boron oxide was formed (Fig. S1 and S2†).

$$
\begin{aligned}
& 2 \mathrm{NH}_{3} \mathrm{BH}_{2} \mathrm{C}\left(\mathrm{NO}_{2}\right)_{3} \rightarrow 2 \mathrm{NH}_{3}+2 \mathrm{H}_{2}+2 \mathrm{NO}_{2} \\
& +\mathrm{N}_{2} \mathrm{O}+2 \mathrm{CO}_{2}+\mathrm{B}_{2} \mathrm{O}_{3}+\mathrm{N}_{2} \\
& 2\left[\mathrm{H}_{2} \mathrm{~B}\left(\mathrm{NH}_{3}\right)_{2}\right]\left[\mathrm{C}\left(\mathrm{NO}_{2}\right)_{3}\right] \rightarrow 4 \mathrm{NH}_{3}+2 \mathrm{H}_{2}+2 \mathrm{NO}_{2} \\
& +\mathrm{N}_{2} \mathrm{O}+2 \mathrm{CO}_{2}+\mathrm{B}_{2} \mathrm{O}_{3}+\mathrm{N}_{2} \\
& 2 \mathrm{~N}_{2} \mathrm{H}_{5} \mathrm{C}\left(\mathrm{NO}_{2}\right)_{3} \rightarrow \mathrm{NH}_{4} \mathrm{C}\left(\mathrm{NO}_{2}\right)_{3}+\mathrm{N}_{2} \mathrm{O}+2 \mathrm{H}_{2} \mathrm{O}+\mathrm{H}_{2} \mathrm{CO}
\end{aligned}
$$

The thermal decomposition pattern of $\mathbf{3 g}$ is different from 3a. The large weight loss of $30.6 \mathrm{wt} \%$, observed at $95{ }^{\circ} \mathrm{C}$ with

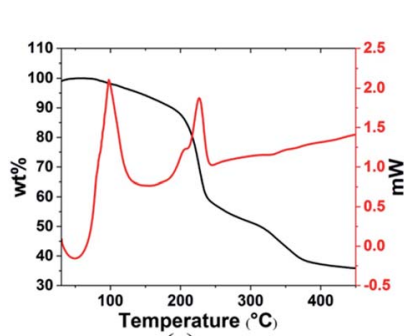

(a)

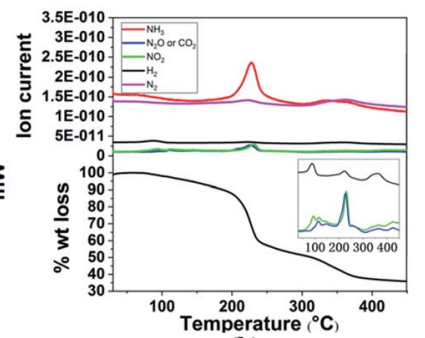

(b)
Fig. 1 (a) TGA and DSC curves and (b) TGA-MS analysis of $3 a$ in the temperature range $30-400{ }^{\circ} \mathrm{C}$ with a heating rate of $3^{\circ} \mathrm{C} \mathrm{min}$.

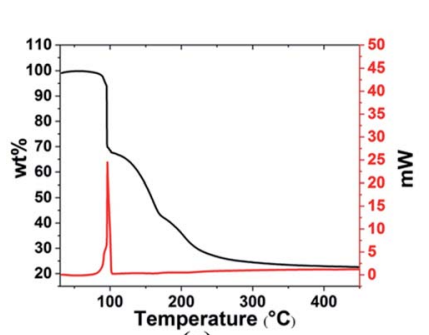

(a)

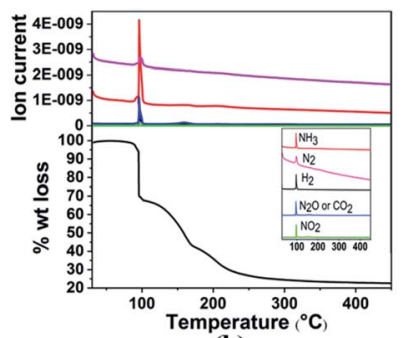

(b)
Fig. 2 (a) TGA and DSC curves (b) TGA-MS analysis of $3 \mathrm{~g}$ in the temperature range $30-400{ }^{\circ} \mathrm{C}$ with a heating rate of $3{ }^{\circ} \mathrm{C} \mathrm{min}-1$.

strongly exothermic, is associated with $\mathrm{H}_{2}, \mathrm{~N}_{2}, \mathrm{NH}_{3}, \mathrm{CO}_{2}, \mathrm{~N}_{2} \mathrm{O}$ and $\mathrm{NO}_{2}$ evolution. At higher temperature, it further decomposes to release $\mathrm{N}_{2} \mathrm{O}, \mathrm{CO}_{2}$ and $\mathrm{NO}_{2}$, resulting in boron oxide (Fig. S3 and S4 $\dagger$ ). The thermal decomposition behaviours of $3 \mathrm{a}$ and $3 \mathrm{~g}$ are different from those of $\mathrm{NH}_{3} \mathrm{BH}_{2} \mathrm{Cl}$, their parent compound. It was recorded that only $\mathrm{H}_{2}$ was released at the initial stage (eqn (4)), and then the second large weight loss was associated with both $\mathrm{H}_{2}$ and $\mathrm{HCl}$ (eqn (5)). At higher temperature, it further decomposes to evolve $\mathrm{HCl}$ and $\mathrm{H}_{2}$ to form boron nitride (eqn (6)). ${ }^{\mathbf{1 1 c}}$

$$
\begin{aligned}
\mathrm{NH}_{3} \mathrm{BH}_{2} \mathrm{Cl} \rightarrow \mathrm{H}_{2}+\left(\mathrm{NH}_{2} \mathrm{BHCl}\right)_{x} \\
\left(\mathrm{NH}_{2} \mathrm{BHCl}\right)_{x} \rightarrow \mathrm{H}_{2}+(\mathrm{NHBCl})_{x} \\
\rightarrow \mathrm{HCl}+(\mathrm{NHBH})_{x} \\
\left(\mathrm{NH}_{2} \mathrm{BHCl}\right)_{x} \rightarrow \mathrm{HCl}+\mathrm{BN} \\
\rightarrow \mathrm{H}_{2}+\mathrm{BN}
\end{aligned}
$$

\section{Conclusions}

In summary, we have developed general methods for the syntheses of both covalent and ionic complexes containing the amine borane reducing group and the trinitromethyl oxidizing group in one molecule under mild conditions. These complexes were successfully isolated in high yields and characterized by NMR and IR. Thermal decomposition was investigated by TGAMS and DSC, and results implicated that compound $\mathbf{3 g}$ may be a promising explosive material. Further studies on the explosive property of $\mathbf{3 g}$ are in progress in our lab.

\section{Experimental}

CAUTION! All nitrogen- and oxygen-rich compounds are potentially explosive energetic materials which should be handled with great care, although no hazards were observed during preparation and handling of these compounds. In any case, it is necessary to take proper precautions by employing all standard energetic materials safety procedures in experiments involving such substances, such as face shields, a leather apron, gloves, and hearing protection should be employed.

\section{General information}

All manipulations were carried out under a nitrogen atmosphere using standard Schlenk techniques and glove box. The 
${ }^{11} \mathrm{~B}$ NMR and ${ }^{11} \mathrm{~B}\left\{{ }^{1} \mathrm{H}\right\}$ NMR spectra were recorded at 128 or 193 $\mathrm{MHz}$ spectrometers and externally referenced to $\mathrm{BF}_{3} \cdot \mathrm{OEt}_{2}$ in $\mathrm{C}_{6} \mathrm{D}_{6}(\delta=0.00 \mathrm{ppm})$. The ${ }^{1} \mathrm{H}$ NMR and ${ }^{1} \mathrm{H}\left\{{ }^{11} \mathrm{~B}\right\}$ NMR spectra were obtained at $600 \mathrm{MHz}$ spectrometer. The ${ }^{13} \mathrm{C}$ NMR spectra were recorded at $151 \mathrm{MHz}$. IR spectra were measured by a Spectrum 400F. X-ray diffraction (XRD) data were obtained with a Rigaku D/max 2500 diffractometer using $\mathrm{Cu} / \mathrm{K} \alpha$ radiation, $\lambda=0.1542 \mathrm{~nm}, 40 \mathrm{kV}, 100 \mathrm{~mA}$. The thermal behaviours of compounds $\mathbf{3 a}$ and $\mathbf{3 g}$ were determined by synchronous thermal analyses (TGA-DSC, Netzsch 449C Jupiter/QMS 403D). The samples were heated to $500{ }^{\circ} \mathrm{C}$ with a heating rate of $3{ }^{\circ} \mathrm{C} \mathrm{min}{ }^{-1}$, under a flowing Ar atmosphere.

Anhydrous nitric acid, sulphuric acid, acetic anhydride, $\mathrm{KOH}$, anhydrous sodium sulfate, ethanol, and iodine were purchased from Sinopharm Chemical Reagents Co., Ltd. $\mathrm{NH}_{3} \mathrm{BH}_{3}, \mathrm{MeNH}_{2} \mathrm{BH}_{3}, \mathrm{Me}_{2} \mathrm{NHBH}_{3}, \mathrm{Me}_{3} \mathrm{NBH}_{3}, \mathrm{BH}_{3} \mathrm{NH}_{2} \mathrm{CH}_{2}$ $\mathrm{CH}_{2} \mathrm{NH}_{2} \mathrm{BH}_{3}$ and $\mathrm{HCl}$ diethyl ether solution $\left(1 \mathrm{~mol} \mathrm{~L}^{-1}\right)$ were purchased from United Boron (Zhengzhou) Energy Materials S\&T LLC and used as received. Tetrahydrofuran (THF), diethyl ether $\left(\mathrm{Et}_{2} \mathrm{O}\right), n$-hexane, and toluene were dried over sodium and freshly distilled prior to use. $N, N$-Dimethylformamide (DMF) was dried by molecular sieves.

Amine chloroborane $(\mathbf{1 a}-\mathbf{d})$ and $\mathrm{K}\left[\mathrm{C}\left(\mathrm{NO}_{2}\right)_{3}\right]$ were prepared according to the literature methods. ${ }^{\mathbf{1 1 , 1 9}}$

1a. Yield: $92 \% ;{ }^{11} \mathrm{~B}$ NMR $(128 \mathrm{MHz}, \mathrm{THF}): \delta-8.73\left(\mathrm{t}, J_{\mathrm{B}-\mathrm{H}}=\right.$ $114.3 \mathrm{~Hz}) \mathrm{ppm}$ (Fig. S5a $\dagger$ ). ${ }^{11} \mathrm{~B}\left\{{ }^{1} \mathrm{H}\right\}$ NMR (128 MHz, THF): $\delta-8.73$ (s) ppm (Fig. S5b†).

1b. Yield: $90 \% ;{ }^{11} \mathrm{~B}$ NMR (193 MHz, THF): $\delta-6.36\left(\mathrm{t}, J_{\mathrm{B}-\mathrm{H}}=\right.$ $120.2 \mathrm{~Hz}) \mathrm{ppm}$ (Fig. S6a $\dagger$ ). ${ }^{11} \mathrm{~B}\left\{{ }^{1} \mathrm{H}\right\}$ NMR (193 MHz, THF): $\delta-6.36$ (s) ppm (Fig. S6b †).

1c. Yield: $86 \% ;{ }^{11} \mathrm{~B}$ NMR $(193 \mathrm{MHz}, \mathrm{THF}): \delta-3.47\left(\mathrm{t}, J_{\mathrm{B}-\mathrm{H}}=\right.$ $120.6 \mathrm{~Hz}) \mathrm{ppm}$ (Fig. S7a $\dagger$ ). ${ }^{11} \mathrm{~B}\left\{{ }^{1} \mathrm{H}\right\}$ NMR (193 MHz, THF): $\delta-3.47$ (s) ppm (Fig. S7b $\dagger$ ).

1d. Yield: $90 \% ;{ }^{11} \mathrm{~B}$ NMR $(193 \mathrm{MHz}, \mathrm{THF}): \delta 0.21\left(\mathrm{t}, J_{\mathrm{B}-\mathrm{H}}=\right.$ 123.0 Hz) ppm (Fig. S8a $\dagger$ ). ${ }^{11} \mathrm{~B}\left\{{ }^{1} \mathrm{H}\right\}$ NMR (193 MHz, THF): $\delta 0.21$ (s) ppm (Fig. S8b†).

K[C(NO $\left.)_{3}\right)_{3}$. Yield of 80\%; IR $\left(\mathrm{cm}^{-1}\right): 1589(\mathrm{~s}), 1363$ (s), 1301 (s), 823 (m), (Fig. S31†).

\section{Synthesis of $\mathrm{ClBH}_{2} \mathrm{NH}_{2} \mathrm{CH}_{2} \mathrm{CH}_{2} \mathrm{NH}_{2} \mathrm{BH}_{2} \mathrm{Cl}$ (1e)}

To a solution of ethylenediaminebisborane $(0.088 \mathrm{~g}, 1 \mathrm{mmol})$ in THF ( $2 \mathrm{~mL}$ ) was added $\mathrm{HCl}$ diethyl ether solution $(2.2 \mathrm{mmol}, 2.2$ $\mathrm{mL}$ ) via syringe at ambient temperature. The reaction was monitored by ${ }^{11} \mathrm{~B} \mathrm{NMR}$ and after about $30 \mathrm{~min}$ the reaction was finished. Then the mixture was filtered and solvent was removed from the filtrate under a dynamic vacuum to leave a white product $(0.144 \mathrm{~g}$, yield $92 \%) .{ }^{11} \mathrm{~B}$ NMR (193 $\mathrm{MHz}$, $\left.\mathrm{CD}_{3} \mathrm{CN}\right): \delta-6.47\left(\mathrm{t}, J_{\mathrm{B}-\mathrm{H}}=107.7 \mathrm{~Hz}\right.$ ) ppm (Fig. S9a $\dagger$ ). ${ }^{11} \mathrm{~B}\left\{{ }^{1} \mathrm{H}\right\}$ NMR (193 MHz, THF): $\delta-6.47$ (s) ppm (Fig. S9b †).

\section{Synthesis of $\left(\mathrm{CH}_{3}\right)_{3} \mathrm{NBH}_{2} \mathrm{I}$ (1f)}

To a solution of trimethylamine borane $(0.073 \mathrm{~g}, 1 \mathrm{mmol})$ in toluene $(2 \mathrm{~mL})$ was added $\mathrm{I}_{2}(0.127 \mathrm{~g}, 0.5 \mathrm{mmol})$ in toluene (5 $\mathrm{mL}$ ) via syringe at ambient temperature. The reaction was monitored by ${ }^{11} \mathrm{~B}$ NMR and after about $1 \mathrm{~h}$ the reaction was finished. After reaction, the mixture was filtered and solvent was removed from the filtrate under a dynamic vacuum to leave a white product $(0.169 \mathrm{~g}$, yield $85 \%) .{ }^{11} \mathrm{~B} \mathrm{NMR}(128 \mathrm{MHz}$, toluene): $\delta-10.57\left(\mathrm{t}, J_{\mathrm{B}-\mathrm{H}}=130.9 \mathrm{~Hz}\right) \mathrm{ppm}$ (Fig. S10a $\dagger$ ). ${ }^{11} \mathrm{~B}\left\{{ }^{1} \mathrm{H}\right\}$ NMR (128 MHz, toluene): $\delta-10.57$ (s) ppm (Fig. S10b $\dagger$ ).

\section{Synthesis of $\left[\left(\mathrm{NH}_{3}\right)_{2} \mathrm{BH}_{2}\right] \mathrm{Cl}(1 \mathrm{~g})$}

Ammonia chloroborane $(0.073 \mathrm{~g}, 1 \mathrm{mmol})$ was placed in a $10 \mathrm{~mL}$ flask, and the $2 \mathrm{~mL}$ of THF was injected into the flask. Then excess $\mathrm{NH}_{3}$ was bubbled into the flask at room temperature and white precipitate was formed immediately. After filtration, THF was removed from the filtrate under dynamic vacuum to leave a white powder product $(0.078 \mathrm{~g}$, yield $94 \%) .{ }^{11} \mathrm{~B}$ NMR (193 MHz, DMF): $\delta-13.54\left(\mathrm{t}, J_{\mathrm{B}-\mathrm{H}}=104.4 \mathrm{~Hz}\right)$ ppm (Fig. S11a $\dagger$ ). ${ }^{11} \mathrm{~B}$ $\left\{{ }^{1} \mathrm{H}\right\}$ NMR (193 MHz, DMF): $\delta-13.54$ (s) ppm (Fig. S11b $\dagger$ ).

\section{General procedure for the synthesis of $\mathrm{ABH}_{2} \mathrm{C}\left(\mathrm{NO}_{2}\right)_{3}(3 \mathrm{a}-\mathrm{c})$}

To a solution of aminoborane (1 mmol) (2a: $0.031 \mathrm{~g} ; 2 \mathbf{b}: 0.045 \mathrm{~g}$; 2c: $0.059 \mathrm{~g})$ in $\mathrm{THF}(2 \mathrm{~mL})$ was added $\mathrm{HCl}$ diethyl ether (1.1 mmol, $1.1 \mathrm{~mL}$ ) via syringe at ambient temperature. The reaction was monitored by ${ }^{11} \mathrm{~B}$ NMR and after about $30 \mathrm{~min}$ the reaction was finished. Then the mixture was filtered and solvent was removed from the filtrate under a dynamic vacuum to leave the products of 1a-c. The prepared 1a-c and $\mathrm{K}\left[\mathrm{C}\left(\mathrm{NO}_{2}\right)_{3}\right]$ $(0.208 \mathrm{~g}, 1.1 \mathrm{mmol})$ were added to the flask and then added $5 \mathrm{~mL}$ diethyl ether at ambient temperature. The yellow solid product was separated by filtration using a filter cannula and dried in vacuo.

3a. Yield: $65 \%(0.117 \mathrm{~g}) ;{ }^{11} \mathrm{~B}$ NMR (193 MHz, $\left.\mathrm{CD}_{3} \mathrm{CN}\right) \delta-4.8$ $\left(\mathrm{t}, J_{\mathrm{B}-\mathrm{H}}=115.9 \mathrm{~Hz}\right.$ ) (Fig. S12a $\dagger$ ). ${ }^{11} \mathrm{~B}\left\{{ }^{1} \mathrm{H}\right\}$ NMR $(193 \mathrm{MHz}$, $\left.\mathrm{CD}_{3} \mathrm{CN}\right) \delta-4.8$ (s) (Fig. S12b $\dagger$ ). ${ }^{1} \mathrm{H}$ NMR (600 MHz, $\left.\mathrm{CD}_{3} \mathrm{CN}\right) \delta 4.4$ $\left(\mathrm{t}, J_{\mathrm{N}-\mathrm{H}}=45.8 \mathrm{~Hz}, 3 \mathrm{H}\right.$ of $\left.\mathrm{NH}_{3}\right), 2.89-2.31\left(\mathrm{~m}, 2 \mathrm{H}\right.$ of $\left.\mathrm{BH}_{2}\right)$ (Fig. S13a $\dagger) .{ }^{1} \mathrm{H}\left\{{ }^{11} \mathrm{~B}\right\} \operatorname{NMR}\left(600 \mathrm{MHz}, \mathrm{CD}_{3} \mathrm{CN}\right) \delta 4.4\left(\mathrm{t}, J_{\mathrm{N}-\mathrm{H}}=\right.$ $45.8 \mathrm{~Hz}, 3 \mathrm{H}$ of $\left.\mathrm{NH}_{3}\right), 2.61$ (s, $2 \mathrm{H}$ of $\mathrm{BH}_{2}$ ) (Fig. S13b $\dagger$ ). IR $\left(\mathrm{cm}^{-1}\right)$ : 3326 (s), 3217 (s), 2448 (w), 1566 (m), 1514 (s), 1411 (s), 1279 (s), 1176 (s), 794 (m), 734 (w) (Fig. S14†).

3b. Yield: $62 \%(0.120 \mathrm{~g}) ;{ }^{11} \mathrm{~B}$ NMR (193 MHz, $\left.\mathrm{CD}_{3} \mathrm{CN}\right) \delta-2.32$ $\left(\mathrm{t}, J_{\mathrm{B}-\mathrm{H}}=116.5 \mathrm{~Hz}\right)$ (Fig. S15a $\dagger$ ). ${ }^{11} \mathrm{~B}\left\{{ }^{1} \mathrm{H}\right\}$ NMR $(193 \mathrm{MHz}$, $\left.\mathrm{CD}_{3} \mathrm{CN}\right) \delta-2.32$ (s) (Fig. S15b $\dagger$ ). ${ }^{1} \mathrm{H}$ NMR (600 MHz, $\mathrm{CD}_{3} \mathrm{CN}$ ) $\delta 4.68\left(\mathrm{t}, J_{\mathrm{N}-\mathrm{H}}=44.0 \mathrm{~Hz}, 2 \mathrm{H}\right.$ of $\left.\mathrm{NH}_{2}\right), 2.95-2.13\left(\mathrm{~m}, 2 \mathrm{H}\right.$ of $\left.\mathrm{BH}_{2}\right)$, $2.35\left(\mathrm{t}, J_{\mathrm{C}-\mathrm{H}}=5.8 \mathrm{~Hz}, 3 \mathrm{H}\right.$ of $\left.\mathrm{CH}_{3}\right)$ (Fig. S16a $\left.\dagger\right) .{ }^{1} \mathrm{H}\left\{{ }^{11} \mathrm{~B}\right\} \mathrm{NMR}(600$ $\left.\mathrm{MHz}, \mathrm{CD}_{3} \mathrm{CN}\right) \delta 4.68\left(\mathrm{t}, J_{\mathrm{N}-\mathrm{H}}=43.0 \mathrm{~Hz}, 2 \mathrm{H}\right.$ of $\left.\mathrm{NH}_{2}\right), 2.53(\mathrm{~s}, 2 \mathrm{H}$ of $\mathrm{BH}_{2}$ ), $2.35\left(\mathrm{t}, J_{\mathrm{C}-\mathrm{H}}=5.8 \mathrm{~Hz}, 3 \mathrm{H}\right.$ of $\mathrm{CH}_{3}$ ) (Fig. S16b $\dagger$ ). ${ }^{13} \mathrm{C} \mathrm{NMR}$ (151 MHz, CD $\left.{ }_{3} \mathrm{CN}\right) \delta 29.48$ (Fig. S17†). IR $\left(\mathrm{cm}^{-1}\right): 3438$ (w), 3093 (w), 1514 (s), 1422 (s), 1384 (s), 1279 (s), 1177 (s), 927 (w), 794 (m), 734 (m) (Fig. S18†).

3c. Yield: $67 \%$ (0.139 g); ${ }^{11} \mathrm{~B}$ NMR (193 MHz, $\left.\mathrm{CD}_{3} \mathrm{CN}\right) \delta 0.22(\mathrm{t}$, $J_{\mathrm{B}-\mathrm{H}}=117.1 \mathrm{~Hz}$ ) (Fig. S19a $\dagger$ ). ${ }^{11} \mathrm{~B}\{\mathrm{H}\} \mathrm{NMR}\left(193 \mathrm{MHz}, \mathrm{CD}_{3} \mathrm{CN}\right)$ $\delta 0.22$ (s) (Fig. S19b†). ${ }^{1} \mathrm{H}$ NMR (600 MHz, CD $\left.{ }_{3} \mathrm{CN}\right) \delta 4.92\left(\mathrm{~s},{ }^{1} \mathrm{H}\right.$ of $\mathrm{NH}), 2.48\left(\mathrm{~d}, J_{\mathrm{C}-\mathrm{H}}=5.7 \mathrm{~Hz}, 6 \mathrm{H}\right.$ of $\left.\mathrm{CH}_{3}\right), 2.90-2.09(\mathrm{~m}, 2 \mathrm{H}$ of $\mathrm{BH}_{2}$ ) (Fig. S20a $\left.\dagger\right) .{ }^{1} \mathrm{H}\left\{{ }^{11} \mathrm{~B}\right\} \mathrm{NMR}\left(600 \mathrm{MHz}, \mathrm{CD}_{3} \mathrm{CN}\right) \delta 4.92\left(\mathrm{~s},{ }^{1} \mathrm{H}\right.$ of $\mathrm{NH}), 2.48\left(\mathrm{~d}, J_{\mathrm{C}-\mathrm{H}}=5.8 \mathrm{~Hz}, 6 \mathrm{H}\right.$ of $\left.\mathrm{CH}_{3}\right), 2.47\left(\mathrm{~s}, 2 \mathrm{H}\right.$ of $\left.\mathrm{BH}_{2}\right)$ (Fig. S20b $\dagger$ ). ${ }^{13} \mathrm{C}$ NMR (151 MHz, $\left.\mathrm{CD}_{3} \mathrm{CN}\right) \delta 39.55$ (Fig. S21†). IR $\left(\mathrm{cm}^{-1}\right)$ : $3441(\mathrm{~m}), 3058(\mathrm{~m}), 2779(\mathrm{~m}), 2435(\mathrm{w}), 1496(\mathrm{~s}), 1422(\mathrm{~s})$, 1384 (s), 1277 (s), 1161 (m), 1022 (w), 924 (w), 793 (m), 733 (m) (Fig. S22†). 


\section{Synthesis of $\left[\mathrm{CH}_{2} \mathrm{NH}_{2} \mathrm{BH}_{2} \mathrm{C}\left(\mathrm{NO}_{2}\right)_{3}\right]_{2}(3 \mathrm{e})$}

To a solution of ethylenediaminebisborane $(0.088 \mathrm{~g}, 1 \mathrm{mmol})$ in THF ( $2 \mathrm{~mL}$ ) was added $\mathrm{HCl}$ diethyl ether solution (2.2 mmol, 2.2 $\mathrm{mL}$ ) via syringe at ambient temperature. The reaction was monitored by ${ }^{11} \mathrm{~B}$ NMR and after about $30 \mathrm{~min}$ the reaction was finished. Then the solvent was removed from the filtrate under a dynamic vacuum to leave product. The prepared $\mathbf{1 e}$ and $\mathrm{K}$ $\left[\mathrm{C}\left(\mathrm{NO}_{2}\right)_{3}\right](0.416 \mathrm{~g}, 2.2 \mathrm{mmol})$ were added to the flask and then added $5 \mathrm{~mL}$ diethyl ether at ambient temperature. The yellow solid product was separated by filtration using a filter cannula and dried in vacuo.

3e. Yield: $62 \%$ (0.239 g); ${ }^{11} \mathrm{~B}$ NMR (193 MHz, $\left.\mathrm{CD}_{3} \mathrm{CN}\right) \delta-2.93$ $\left(\mathrm{t}, J_{\mathrm{B}-\mathrm{H}}=116.6 \mathrm{~Hz}\right)$ (Fig. S23a $\left.\dagger\right) .{ }^{11} \mathrm{~B}\{\mathrm{H}\} \mathrm{NMR}\left(193 \mathrm{MHz}, \mathrm{CD}_{3} \mathrm{CN}\right)$ $\delta-2.94$ (s) (Fig. S23b $\dagger$ ). ${ }^{1} \mathrm{H}$ NMR (600 MHz, $\left.\mathrm{CD}_{3} \mathrm{CN}\right) \delta 4.91(\mathrm{~s}, 2 \mathrm{H}$ of $\left.\mathrm{NH}_{2}\right), 2.98\left(\mathrm{~s}, 3 \mathrm{H}\right.$ of $\left.\mathrm{CH}_{3}\right), 2.90-2.18\left(\mathrm{~m}, 2 \mathrm{H}\right.$ of $\left.\mathrm{BH}_{2}\right)$ (Fig. S24a $\dagger$ ). ${ }^{1} \mathrm{H}\left\{{ }^{11} \mathrm{~B}\right\}$ NMR $\left(600 \mathrm{MHz}, \mathrm{CD}_{3} \mathrm{CN}\right) \delta 4.91$ (s, $2 \mathrm{H}$ of $\mathrm{NH}_{2}$ ), 2.98 (s, 3H of $\mathrm{CH}_{3}$ ), 2.56 (s, $2 \mathrm{H}$ of $\mathrm{BH}_{2}$ ) (Fig. S24b $\dagger$ ). ${ }^{13} \mathrm{C}$ NMR (151 MHz, CD ${ }_{3} \mathrm{CN}$ ) $\delta 42.28$ (Fig. S25†). IR ( $\mathrm{cm}^{-1}$ ): $3172(\mathrm{w})$, 3057 (w), 1608 (w), 1519 (w), 1361 (m), 1296 (s), 1087 (m), 1032 (m), 918 (m), 822 (m), 778 (m), 692 (m), 461 (w) (Fig. S26†).

\section{Synthesis of $\left[\mathrm{H}_{2} \mathrm{~B}\left(\mathrm{NH}_{3}\right)_{2}\right]\left[\mathrm{C}\left(\mathrm{NO}_{2}\right)_{3}\right](3 \mathrm{~g})$}

To a solution of ammonia borane $(0.031 \mathrm{~g}, 1 \mathrm{mmol})$ in THF (2 $\mathrm{mL}$ ) was dropwise added $\mathrm{HCl}$ diethyl ether $(1.1 \mathrm{mmol}, 1.1 \mathrm{~mL})$ via syringe at ambient temperature. The white solid product (1a) was separated by filtration using a filter cannula dried in vacuo for use.

(a) Repeated the literature method. The prepared 1a was placed in a flask, and the $2 \mathrm{~mL}$ of THF was injected into the flask. Then excess $\mathrm{NH}_{3}$ was bubbled into the flask for $30 \mathrm{~min}$ under stirring at room temperature and white precipitate was produced immediately. Then $\mathrm{K}\left[\mathrm{C}\left(\mathrm{NO}_{2}\right)_{3}\right](0.208 \mathrm{~g}, 1.1 \mathrm{mmol})$ in THF ( $5 \mathrm{~mL}$ ) was added into the flask, the reaction mixture was stirred for $2 \mathrm{~h}$ and the solution turned from colourless and transparent to yellow. After filtration to remove the formed $\mathrm{KCl}$, THF was removed from the filtrate under dynamic vacuum to give a yellow powder product $(3 \mathrm{~g}, 0.129 \mathrm{~g}$, yield $65 \%)$.

(b) The prepared 1a and $\mathrm{K}\left[\mathrm{C}\left(\mathrm{NO}_{2}\right)_{3}\right](0.208 \mathrm{~g}, 1.1 \mathrm{mmol})$ were added to a flask and then $5 \mathrm{~mL}$ of liquid $\mathrm{NH}_{3}$ was condensed into the flask at $-78{ }^{\circ} \mathrm{C}$ and stirred for 2 hours. Then the reaction was warm up to room temperature and liquid $\mathrm{NH}_{3}$ was volatilized completely to leave white and yellow powder precipitate ( $\mathrm{KCl}$ and $\mathbf{3 g}$ ). The yellow precipitate was extracted with $20 \mathrm{~mL}$ of THF. Removal of THF from the filtrate under dynamic vacuum gave a yellow powder product $(0.133 \mathrm{~g}$, yield $68 \%)$.

(c) The prepared $1 \mathrm{a}$ and $\mathrm{K}\left[\mathrm{C}\left(\mathrm{NO}_{2}\right)_{3}\right](0.208 \mathrm{~g}, 1.1 \mathrm{mmol})$ were added to a flask and the $5 \mathrm{~mL}$ of ethyl ether was injected into the flask. The reaction was stirred for $2 \mathrm{~h}$, then excess $\mathrm{NH}_{3}$ was bubbled into the flask and white precipitate was produced immediately, the solution turned to yellow. Removal of ethyl ether from the filtrate under dynamic vacuum gave a yellow product (3g, $0.117 \mathrm{~g}$, yield 59\%).

3g. ${ }^{11} \mathrm{~B}$ NMR $\left(193 \mathrm{MHz}, \mathrm{CD}_{3} \mathrm{CN}\right) \delta-13.06\left(\mathrm{t}, J_{\mathrm{B}-\mathrm{H}}=110.9 \mathrm{~Hz}\right)$ (Fig. S27a $\dagger$ ). ${ }^{11} \mathrm{~B}^{1}\{\mathrm{H}\}$ NMR (193 $\left.\mathrm{MHz}, \mathrm{CD}_{3} \mathrm{CN}\right) \delta-13.05(\mathrm{~s})$ (Fig. S27b $\dagger$ ). ${ }^{1} \mathrm{H}$ NMR $\left(600 \mathrm{MHz}, \mathrm{CD}_{3} \mathrm{CN}\right) \delta 4.40\left(\mathrm{t}, J_{\mathrm{N}-\mathrm{H}}=\right.$
$47.4 \mathrm{~Hz}, 6 \mathrm{H}$ of $\mathrm{NH}_{3}$ ), 2.40-1.56 (m, $2 \mathrm{H}$ of $\mathrm{BH}_{2}$ ) (Fig. S28a†). ${ }^{1} \mathrm{H}$ $\left\{{ }^{11} \mathrm{~B}\right\} \mathrm{NMR}\left(600 \mathrm{MHz}, \mathrm{CD}_{3} \mathrm{CN}\right) \delta 4.40\left(\mathrm{t}, J_{\mathrm{N}-\mathrm{H}}=47.6 \mathrm{~Hz}, 6 \mathrm{H}\right.$ of $\mathrm{NH}_{3}$ ), $2.02\left(\mathrm{~m}, 2 \mathrm{H}\right.$ of $\mathrm{BH}_{2}$ ) (Fig. S28b $\dagger$ ). IR $\left(\mathrm{cm}^{-1}\right): 3274(\mathrm{~m}), 2444$ (w), 2409 (w), 2338 (w), 1514 (s), 1408 (s), 1384 (s), 1273 (s), 1173 (m), $1093(\mathrm{w}), 1028(\mathrm{w}), 869(\mathrm{w}), 792(\mathrm{~s}), 734(\mathrm{~s}), 693(\mathrm{w})$ (Fig. S29†).

\section{Conflicts of interest}

There are no conflicts to declare.

\section{Acknowledgements}

This work was supported by the National Natural Science Foundation of China (Grant Numbers: 21771057 to X. C., 22001061 to X.-M. C.) and China Postdoctoral Science Foundation (Grant Numbers: 2020M682309 to X.-M. C.).

\section{Notes and references}

1 (a) A. Hantzsch and A. Rinckenberger, Ber. Dtsch. Chem. Ges., 1899, 32, 628-641; (b) A. A. Gidaspov, V. V. Bakharev and I. K. Kukushkin, Russ. Chem. Bull., 2009, 58, 2154-2163; (c) V. Thottempudi, H. Gao and J. M. Shreeve, J. Am. Chem. Soc., 2011, 133, 6464-6471; (d) O. G. Jolodar, K. Ghauri, M. Seddighi, F. Shirini and Y. Bayat, J. Mol. Struct., 2019, 1186, 448-457; (e) A. A. Gidaspov, V. A. Zalomlenkov, V. V. Bakharev, V. E. Parfenov, E. V. Yurtaev, M. I. Struchkova, N. V. Palysaeva, K. Y. Suponitsky, D. B. Lempert and A. B. Sheremetev, RSC Adv., 2016, 6, 34921-34934.

2 (a) O. P. Shitov, V. A. Tartakovsky, I. S. Golovanov, A. Y. Sukhorukov and S. L. Ioffe, Chem.-Asian J., 2017, 12, 2237-2244; (b) O. P. Shitov, V. A. Tartakovskii and S. L. Ioffe, Chem. Heterocycl. Compd., 2015, 12, 1647-1657; (c) S. L. Ioffe, A. S. Shashkov, A. L. Blyumenfel'd, L. M. Leont'eva, L. M. Makarenkova, O. B. Belkina and V. A. Tartakovskii, Bull. Acad. Sci. USSR, Div. Chem. Sci., 1976, 25, 2371-2379; (d) S. L. Ioffe, A. V. Kalinin, B. N. Khasapov, L. M. Leont'eva and V. A. Tartakovskii, Bull. Acad. Sci. USSR, Div. Chem. Sci., 1978, 27, 1019-1021; (e) O. P. Shitov, L. M. Leont'eva, S. L. Ioffe, B. N. Khasanov, V. M. Novikov, A. U. Stepanyants and V. A. Tartakovskii, Bull. Acad. Sci. USSR, Div. Chem. Sci., 1974, 23, 2684-2691; (f) S. L. Ioffe, A. V. Kalinin, T. N. Golovina, B. N. Khasapov and V. A. Tartakovskii, Bull. Acad. Sci. USSR, Div. Chem. Sci., 1978, 27, 816-819.

3 T. M. Klapötke and B. K. Richard Moll, Chem.-Eur. J., 2013, 36, 12113-12123.

4 T. M. Klapötke, B. Krumm, M. Rusana and J. J. Sabatini, Chem. Commun., 2014, 50, 9581-9583.

5 G. Bélanger-Chabot, M. Rahm, R. Haiges and K. O. Christe, Angew. Chem., Int. Ed., 2013, 52, 11002-11006.

6 G. Bélanger-Chabot, M. Rahm, R. Haiges and K. O. Christe, Angew. Chem., Int. Ed., 2015, 54, 11730-11734.

7 (a) M. Liu, L. Zhou, X. Luo, C. Wan and L. Xu, Catalysts, 2020, 10, 788-822; (b) U. B. Demirci, Energies, 2020, 13, 3071-3115; 
(c) U. B. Demirci, Int. J. Hydrogen Energy, 2017, 42, 997810013; (d) A. Rossin and M. Peruzzini, Chem. Rev., 2016, 116, 8848-8872; (e) Y. Lin and W. L. Mao, Chin. Sci. Bull., 2014，59，5235-5240; (f) V. Rizzi, D. Polino, E. Sicilia, N. Russo and M. Parrinello, Angew. Chem., Int. Ed., 2019, 58, 3976-3980.

8 (a) H. Li, Qi. Yang, X. Chen and S. G. Shore, J. Organomet. Chem., 2014, 751, 60-66; (b) H. Li, R. Wang, Q. Xia, Q. Yang, P. Wang, C. Wei, N. Ma and X. Chen, Chem. Res., 2018, 29, 118-124; (c) C. Cui, Y. Ma, J. Zhang and X. Chen, Chem. Res., 2019, 30, 454-462.

9 (a) P. J. Silva and M. J. Ramos, J. Org. Chem., 2009, 74, 61206129; (b) E.-C. Koch and T. M. Klapötke, Propellants Explos. Pyrotech., 2012, 37, 335-344; (c) P. Srivastava and H. J. Singh, J. Energ. Mater., 2010, 28, 202-218; (d) H. A. LeTourneau, R. E. Birsch, G. Korbeck and J. L. Radkiewicz-Poutsma, J. Phys. Chem. A, 2005, 109, 12014-12019; (e) D. H. Campbell, T. C. Bissot and R. W. Parry, J. Am. Chem. Soc., 1958, 80, 1549-1552.

10 (a) S. Toyota, T. Futawaka, M. Asakura, H. Ikeda and M. Oki, Organometallics, 1998, 17, 4155-4163; (b) A. P. M. Robertson, M. F. Haddow and I. Manners, Inorg. Chem., 2012, 51, 82548264; (c) H. K. Lingam, X. Chen, J.-C. Zhao and S. G. Shore, Chem.-Eur. J., 2012, 18, 3490-3492; (d) R. Kumar and B. R. Jagirdar, Inorg. Chem., 2013, 52, 28-36; (e) C. T. Hoang, I. Prokes, G. J. Clarkson, M. J. Rowland, J. H. R. Tucker, M. Shipman and T. R. Walsh, Chem. Commun., 2013, 49, 2509-2511; (f) B. Icli, E. Sheepwash, T. Riis-Johannessen, K. Schenk, Y. Filinchuk, R. Scopellitia and K. Severin, Chem. Sci., 2011, 2, 1719-1721.

11 (a) M. G. Hu and R. A. Geanangel, Inorg. Chem., 1979, 18, 3297-3301; (b) D. R. Ketchum, A. L. DeGraffenreid, P. M. Niedenzu and S. G. Shore, J. Mater. Res., 1999, 14, 1934-1938; (c) H. K. Lingam, C. Wang, J. C. Gallucci, X. Chen and S. G. Shore, Inorg. Chem., 2012, 51, 1343013436.

12 (a) O. J. Metters, A. M. Chapman, A. P. M. Robertson, C. H. Woodall, P. J. Gates, D. F. Wass and I. Manners, Chem. Commun., 2014, 50, 12146-12149; (b) C. R. Balulescu and P. C. Keller, Inorg. Chem., 1978, 17, 3707-3708; (c) O. T. Beachley and B. Washburn, Inorg. Chem., 1975, 14, 120-123; (d) W. H. Myers, G. E. Ryschkewitsch, M. A. Mathur and R. W. King, Inorg. Chem., 1975, 14, 2874-2881; (e) W. H. Myers and G. E. Ryschkewitsch, Inorg. Chem., 1978, 17, 1157-1159.

13 (a) P. J. Bratt, K. R. Seddon and I. A. Steer, Inorg. Chim. Acta, 1974, 10, 191-195; (b) M. P. Brown, R. W. Heseltine, P. A. Smith and P. J. Walker, J. Chem. Soc. A, 1970, 410414; (c) H. C. Kelly, S. C. Yasui and R. B. Twiss-Brooks, Inorg. Chem., 1984, 23, 2220-2223; (d) W. H. Myers, G. E. Ryschkewitsch, M. A. Mathur and R. W. King, Inorg. Chem., 1975, 14, 2874-2881.

14 (a) D. R. Schultz and R. W. Parry, J. Am. Chem. Soc., 1958, 80, 4-8; (b) S. G. Shore and R. W. Parry, J. Am. Chem. Soc., 1958, 80, 8-12; (c) S. G. Shore and R. W. Parry, J. Am. Chem. Soc., 1958, 80, 12-15; (d) R. W. Parry and S. G. Shore, J. Am. Chem. Soc., 1958, 80, 15-20; (e) H. K. Lingam, X. Chen, J.-C. Zhao and S. G. Shore, Chem.-Eur. J., 2012, 18, 34903492 .

15 (a) U. Vogel, P. Hoemensch, K.-C. Schwan, A. Y. Timoshkin and M. Scheer, Chem.-Eur. J., 2003, 9, 515-519; (b) C. Marquardt, A. Adolf, A. Stauber, M. Bodensteiner, A. V. Virovets, A. Y. Timoshkin and M. Scheer, Chem.-Eur. J., 2013, 19, 11887-11891; (c) C. Marquardt, C. Thoms, A. Stauber, G. Balázs, M. Bodensteiner and M. Scheer, Angew. Chem., Int. Ed., 2014, 53, 3727-3730.

16 (a) M. Göbel, T. M. Klapötke and P. Mayer, Z. Anorg. Allg. Chem., 2006, 632, 1043-1050; (b) A. A. Gakh, J. C. Bryan, M. N. Burnett and P. V. Bonnesen, J. Mol. Struct., 2000, 520, 221-228.

17 (a) R. W. Parry and S. G. Shore, J. Am. Chem. Soc., 1958, 80, 15-20; (b) X. Chen, X. Bao, J.-C. Zhao and S. G. Shore, J. Am. Chem. Soc., 2011, 133, 14172-14175.

18 O. E. Dragomir, M. J. Tummers, E. H. van Veen, A. E. D. M. van der Heijden and D. J. E. M. Roekaerts, Combust. Flame, 2009, 156, 1810-1817.

19 Y. Huang, H. Gao, B. Twamley and J. M. Shreeve, Eur. J. Inorg. Chem., 2007, 2025-2030. 